\title{
TABUS LINGÜISTICOS
}

R. F. Mansur Guérios

(continuação)

\section{A NOITE E O PODER DAS TREVAS.}

A escuridão sempre apavorou os homens, quer a que se verifica com a noite, quer a que se manifesta com os eciipses, quer, enfim, a dos lugares esconsos ou não dotados de luz. Tal se explica pela crença de que os espíritos malignos agem no escuro, e, por outro lado, não é sem razão que a Bíblia fala nc poder das trevas.

Se a escuridão causa pavor, não é de admirar que as palavras que a traduzem — "trevas, "noite", "escuro", etc. — sejam tabuizadas, e não só, senão ainda, entre muitos povos, vários assuntos, frases ou palavras não podem ser proferidos durante a noite.

E o lugar onde jazem os espíritos é a própria escuridăo (89-b). " $\mathrm{Na}$ mitologia grega e romana, os Infernos são os lugares subterrâneos onde descem as almas depois da morte para ser julgadas, e receber o castigo dos seus crimes ou a recompensa das boas ações". "Esses lugares subterrâneos, situados a uma profundidade incomensurável, em baixo da Grécia e da Itália, estendiam-se até os extremos confins do mundo então conhecido; e assim como a Terra era cercada pe!o rio Oceano, êles eram circunscritos e limitados pelo reino da Noite" (90).

Entre os Romanos, as palavras inferi ("habitantes do mundo subterrâneo"), inferiae ("sacrifício oferecido aos manes"), inferni

(89-b) Mas, pode suceder, como entre os Caiovás, que acendem uma fogueira sôbre a sepultura do índio, na noite do entêrro, apenas para "a alma encontrar o caminho para o Além" (ECON SCHADEN, Aspectos Fundamentais da Cultura Cuarani, vol. n. 118, Fac. Filos. da Univ. de S. Paulo, 1954, p. 156).

(90) P. COMMELIN, Nova Mitologia Grega e Romana, trad., 4. ${ }^{a}$ ed., p. 216. 
("infernos, morada dos deuses inferi") foram tomadas a um dialeto itálico não identificado. As correspondentes, com -d-, puramente latinas — ${ }^{*}$ inderi, *inderiae, ${ }^{*}$ inderni — de propósito evitadas, incompletamente, porque, de uso religioso, "têm relação com um mundo que se evitava nomear, o dos sêres subterrâneos, dos mortos..." (91). Cp. as frases gregas de vários autores hupò gên eînai, "estar sob a terra, nos infernos"; oì hupò chthonós, "os que estão sob a terra, os mortos" ; hupò chthonós Tártaros, "o Tártaro sob a terra"; dómon Haidos eíso, "descer sob a terra, na morada de Hades, i. é, morrer"; oì mákares chthónioi, "os felizes terrestres, i. é, os deuses infernais", etc.

Entre os Sumeros Giguna e Aráli, entre os Assirios e Babilônicos Arálu é o "mundo subterrâneo, a habitação das trevas".

Na mitologia mundurucu — ipirawat - é o "habitante do interior da terra" (C. Strömer).

O fenômeno se repete na atualidade. No inglês, evita-se, às vêzes, o nome do inferno hell, substituido pelo desfigurado heck, de origem dialetal.

Se bem que no Brasil, em geral, não se evita inferno, é, nas imprecações populares, substituido por quintos — "vá para os quintos!" - que parece, contudo, abreviação de quintos dos infernos.

"Tanto na Grécia como na Itália, era crença geral que tôdas as cavernas, tôdas as anfractuosidades, as fendas do solo cuja profundidade ninguém nunca sondara, podiam estar em comunicação com os Infernos" (P. COMMELIN) (91-a).

Assim é que se concretiza, nas línguas indo-européias, essa crença remota, que sofreu também o influxo da tabuização: 0

(91) A. MEILLET, Esquisse d'une Histoire de la Langue Latine, 4. ${ }^{\circ}$ ed., p. 400. ERNOUT-MEILLET, Dict. Étym. de la L. Lat., s. v. inferus. É provável que as demais palavras corradicais — *inderus, “inderior, *indimus, *indra, de uso nāo religioso (?), foram adaptadas às com -f-: inferus, inferior, infimus, infra.

(9]-a) I. M. PIEL explica o étimo do port. orca, "anta, dólmen", filiando-o ao lat. orcus, "inferno", e justifica-o com "a tendência da fantasia popular para interpretar uma caverna profunda como sendo uma entrada do inferno". E lembra o topônimo port. Poço do Inferno. A isto acrescentamos o Beco do Inferno da velha Curitiba, hoje Travessa Marumbi. A propósito, v. BERNARDES, Nova Floresta, II, 1949, p. 269. 
latim fundus, "fundo da terra, etc.", dizem ERNOUT e MEILLET (92), "pertence a um grupo de palavras evidentemente aparentadas mùtuamente, mas cujas formas diferem muito para que se possam estabelecer originais indo-europeus". E continuam: "A explicação dêsse fato - que é de caráter religioso - foi dada por VENDRYĖS. Este, relacionando-o com o vocábulo mundus, que designava uma cavidade hemisférica encravada no solo por onde se comunicava com o mundo subterrâneo, admite o parenteco com aquêle. Não resta dúvida; trata-se de deformação fonética de natureza tabuística.

Vamos enfileirar os vários correspondentes aparentados entre si e daquelas palavras (indicam solo, mundo, caverna, abismo, fundo, profundo, vale, garganta de montanha, etc.): $1 .^{\circ}$ ) sânscr. budhnáh, alto alemão ant. bodam, grego buthós; $2 .$. ) zende buna, irlandês bond, grego púndax; $3 .^{\circ}$ ) eslavo antigo duno, lit. dùgnas, armeno -dundk, gaulês dubnodumno-, íit. dubús, daubà, irl. domain, domun, esl. ant. dubri, dupuka, dupinu, duplu, gót. diups, médio alto alem. tobel.

Distinguiam-se nos infernos quatro regiões principais - o Érebo, o Inferno dos maus, o Tártaro e os Campos Elísios, morada feliz das almas virtuosas.

"No Érebo viam-se os palácios da Noite, do Sono e dos Sonhos; era a morada de Cérbero, das Fúrias e da Morte. Era aí que erravam durante cem anos as desgraçadas sombras cujos corpos não tinham recebido sepultura" (P. COMMELIN).

As sombras foram tidas como almas dos viventes. Na Grécia como na Itália, a palavra que indica "sombra", está potenciada de idéias sobrenaturais: O grego skiá, além de simples sombra, quer dizer "sombra dos mortos" e "fantasma", como o sinônimo skótos, "trevas", "trevas da morte" "trevas do inferno", "infernos". Em latim, umbra vale também por "sombra dos mortos", "espectro" (umbrarum rex é Plutão, rei dos Infernos — Ovídio); umbrae, além de "sombras dos mortos", é também "infernos"; umbrare manes é "encerrar os manes nas trevas".

A sombra é personificada. em grego, sob a expressão nukteropos (93), que se traduz "vista ou face da noite". 
Em guaiaqui (idioma indígena do Paraguai), Anyavé significa "sombra" e é o nome de um gênio do bem e do mal (G. T. BERTONI).

Entre os Bacairis, a morte é a separação definitiva do corpo efetuada pela sombra (= alma) (94).

Entre os Mundurucus, "sombra" e "espírito" são uma mesma palavra (axik ou bihumbök).

O grego thánatos, "morte", o gótico dauthus, o alemão tod, estão assentes na idéia de "trevas"; são corradicais do sânscrito dhvanta-, "escuridão".

Entre os Nhandevas ou Guaranis, cada individuo possui três almạs, "visíveis em forma de sombras". L'ma delas - anguêry a da esquerda, é "ruim": "faz mal; traz doença e às vêzes a morte" (94-a). E' curioso que ela vagueia não só de noite, mas também ao meio-dia.

Em tupí, anga quer dizer "sombra" e "alma".

Entre os Basutos (África sueste), Modimo ou Morimo é o nome de um deus terrestre, espirito, fantasma, cujo radical — di, dim - quer dizer "negro, escuro" (95).

Adaeg ou Ataecina é uma deusa da Lusitânia céltica; trata-se de uma divindade infernal. O nome é cognato do irl. adaig, "noite" (95-a).

A herança das crenças antiquiíssimas está presente também no português: sombra, "alma, espírito, visão, fantasma; a região Jos mortos", assombrado, malassombrado, assombramento, assombrar, assombração, sombrio, etc.

Negra, popularmente, em Portugal, quer dizer "morte" (). S. CORREIA).

Assim se explica, pois, que em grego o nome da "noite", das "trevas", etc., tabuizado, apresenta-se multiforme, como que, alterando-se-lhe os fonemas, exconjuram-se as potências maléfi-

(94) "As sombras dos Bacairis mortos vāo para o céu, junto dos antepassa. dos" (K. VON DEN STEINEN, Entre os Aborigines do Brasil Central, S. Paulo, 1940, p. 449).

(94-a) ECON SCHADEN, Aspectos Fundamentais da Cultura Cuarani, S. Paulo, 1954, p. 128 e segs.

(95) O. ASSIRELLI, Africa Polyglotta, Bolonha, 1938, p. 338.

(95-a) C. HERNANDO BALMORI "apud" ANTONIO TOVAR, Latín vulgar, latín de Hispania "in" Jornal de Filol., S. P., 8, 1955, p. 85. 
cas das trevas: dnóphos = gnóphos, "obscuridade, trevas" = zóphos, "escuridão, trevas dos irifernos"; dnopherós = zopherós = psepharós, "sombra" = pséphas = pséphos, "escuridão"; knéphas, knéphos, "obscuridade, crepúsculo" = knephaios, "sombra". Contudo, criou-se uma palavra nova - euphróne, verdadeiro eufemismo que, todavia, coincide subrepticiamente no fonema medial -ph-, como que não querendo ficar isolado. Euphróne, "a noite", "a escuridão", quer dizer "a benevolente, a benfazeja, a conselheira".

VENDRYES cita outra metáfora para "noite" -abróte- "a em que não há ninguém" (96). Trata-se de antífrase, expediente tabuístico, como que a dizer "onde não há espíritos".

Mais de um vocábulo possuia o sânscrito para a idéia de "noite": nisa, ratri, e outros, a'ém de nakt-, como membro de composto.

$O$ que aconteceu com o grego, igualmente se verificou nos idiomas germânicos - desfiguramento do vocábulo que traduz "escuro", e o fenômeno remonta à fase árica: alto alem. ant. demar, anglo-sax. thimm, sânscr. támas- (com t- indo-eur.), mas nórdico ant. dimmr, anglo-sax. $\operatorname{dim}(m)$, sueco ant. dimbar, alto alem. ant. timbar (com dh-i.-e.).

Parece que se pode aliar a forma demar ou timbar (deriv. de

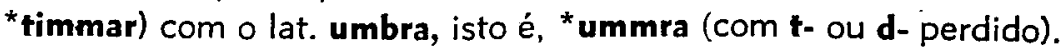
Para a variação vocálica, cp. letão timsa, tumsa, "escuridão".

Curiosa é a forma do bretão teffal, "sombra", que, de certo modo, lembra o irlandês ant. temel, "trevas".

Corradical das formas com a labial -m- é a série com -n-: a to al. ant. finstar, thinstar, dinstar $=$ lat. tenebrae $(97)=$ alem. dunkel, alto al. ant. tunchal (98), frisão ant. diunk $(99)=$ védico ándhah, "escuridão" = línguas eslavas teni, seni, steni, "sombra".

Outra oposição verifica-se na inicial entre o lat. fuscus, "fosco, escuro", anglo-sax. dox, "escuro", com dh- i.-e., e anglo-sax.

(96) Le Langage, 1921, p. 259.

(97) Não é questão dirimida, se tenebrae provém de *tem- (E. M., Dict. Erym. de la L. Lat., s. v.).

(98) São dignas de reparo as formas germ. tunchal, dunkel com as neocélticas teffal, temel.

(99) Observa-se aí a variação vocálica i e u com as formas dotadas da labial -m-. 
ge-thuxad, "escuro", com t- i.-e., ou anglo-sax. deorc, "escuro", deoreung, "crepúsculo", com dh-i.-e., frente ao anglo-sax. theorcung "crepúsculo", com t- indo-europeu.

Nota-se uma esquisita "corespondência" -sp- = -k-, na idéia de "tarde", entre o latim vesper, grego hésperos, de um lado, e, de outro, o lituano väkaras, eslavo ant. vetcheru, gaulês ucher e armeno gisher; o ir andês parece participar das duas séries sob a forma fescor. Acrescente-se ao conjunto o germ. west, "oeste, ocidente" (100).

À forma acima do grego knéphas, "escuridão, crepúsculo", corresponde esquisitamente o sânscrito ksap- e o sabino *crepeso-. Ėste, provável, passou ao lat. crepus(culum), creper.

Em várias línguas, palavras que indicam "escuridão da noite, crepúsculo" apresentam-se sob a forma do plural. Não se trata de aspecto do aumentativo, mas de recurso eufemístico, pois a idéia do singular nos leva a uma determinação que, na concepção supersticiosa, predispõe ao perigo, o que não sucede com o plural, pois é modalidade de generalização. Sirvam de exemplo o lat. tenebrae, umbrae, o sânscr. tamisrah, tamasi, o lituano támsumai, tamses, o grego skótoi, dnóphoi, etc. (HAVERS). HOME$\mathrm{RO}$, em vez de "noite e dia", usa da fórmula núktas te kaì hêmar, i. é. "noites e dia" (100-a).

Diz MEILLET que o nome do "sono" em grego (húpnos), em latim (somnus), etc., é do gênero masculino, porque "o sono é uma fôrça poderosa que submete os homens à sua vontade". Por outro lado, é do gênero neutro "o objeto que aparece no sono" - o sonho: enúpnion em grego, somnium em latim, súnije em eslavo, svápn(i)yam em sânscrito (100-b).

Trata-se, muito plausivelmente, do recurso de neutralizar as fôrças malvadas que freqüentemente se manifestam através dos sonhos, sempre temidos em todos os povos.

Os Araucanos designam com nomes especiais os animais, conforme estejam falando de dia ou à noite. Durante as horas

(100) Para a semântica, cp. gr. hespéra, "oeste", e zéphuros, "*tarde", "* oeste", isto é, "“escuro".

(100-a) MEILLET, Linguistique Hist. et Ling. Gén., I, Paris, 1926, p. 226.

(100-b) Ibidem, p. 222. 
de trabalho, o jaguar é chamado por seu próprio nome - aroá; quando, todavia, é escuro, dão-lhe a denominação de kabadaro, i. é, "as garras".

Em regiões da Índia, a cobra, à luz do dia, é samp (= sânscr. sarpa); de noite é dushmen, "inimigo" (vocábulo persa).

$\mathrm{Na}$ Is ândia, a rapôsa, à noite, não é citada pelo seu nome.

Os Russos da Sibéria estão convencidos de que os espíritos maus aparecem à meia-noite e desaparecem ao cantar do galo. $E$ aquêle que dirige a palavra a um chefe depois do crepúsculo, deve empregar outro nome e perífrases.

Também para a própria noite empregam-se na India substitutivos ou palavras encobertas, de que é muito rico a sânscrito.

Os pescadores da baía de Patani (Península malaia) têm uma linguagem especial mais obrigatória de noite que de dia.

As histórias do Bechuanas (África do sul) sòmente são narradas antes do pôr-do-sol. Em caso contrário, cairiam as nuvens nas cabeças de todos.

A terra dos Francos, ao norte das Gálias, foi dividida, no tempo dos Merovíngios, em duas partes - uma a leste, a Austria < germ: auster, "oriental", e outra, a oeste, a Neustria $<$ Neu Austria, "Nova Austria", em vez do germ. wester, "ocidental". Há tabu com referência ao oeste, ao ocidente.

Os Godos ocidentais se chamam Wisigothi (Visigodos); não quer dizer "Godos do oeste", mas "Godos bons, excelentes" (101). Isto é devido, segundo KRETSCHMER, a um antigo receio supersticioso à denominação das terras e dos povos do ocidente, como região dos mortos e sede dos espíritos, terras de sombras (102), poi aí desaparece a luz do Sil e domina totalmente a noite (102-a).

(101) M. SCHONFELD, Wörterbuch der Altgermanischen Personen und Völkernamen, Haidelbergue, 1911, p. 268. E Ostrogodos são os Godos do Leste, i. é, "da luz, do sol nascente".

(102) HAVERS, \& 48, p. 102.

(102-a) Os Guaranis enterram "os mortos (em posição deitada) com os pés para o nascente" - a fim de, explicou o indio Capitão Alberto "o espirito encontrar o caminho do Sol". "Na realidade, acrescenta ECON SCHADEN, trata-se da ida para o yvy' mará eým, o paraíso mistico dos Guarani, que muitos acreditam estar situado na direção de leste" [Terra sem males] ("Aspectos Fundamentais da Cultura Guarani", S. Paulo, 1954, p. 158-159). 


\section{ADENDA:}

Ao cap. 9 - tabus em nomes de autoridade:

"Um a faqui de Almeria (séc. Xl), ouvindo a um judeu, vizir do rei, repetir ya Mohammadel [diminutivo familiar] para chamar um moço cujo nome era Mohammad, matou com uma pedrada o vizir, sem dúvida indignado por ouvir o nome do profeta sob essa forma vulgar irreverente" (M. Pidal, "Orígenes del Español", 3. ${ }^{\circ}$ ed., p. 151 ).

Ao cap. 10 - tabus em nomes religiosos:

Na italiano, agora desusado, a exclamação affé di Dio, "à fé de Deus", por um voto ou juramento ou ameaça, apresentava-se eufemisticamente — affeddedieci, affeddedina (Zingarelli, "Vocab.").

Deformações voluntárias usadas no espanhol do fim do séc. 16: pardiós, pardiego, pardiola; a fim de não dizerem — voło a Dios - empregavam: voto no a Dios, voto a nadie, voto a briós, voto a rus, voto a diez, voto a ños, por Santoval, voto a San Junco, voto a sanes, pese a diex. juro a mi, voto al chápiro ("Rev. Port. de Filol.", 1948, p. 420).

Admite-se que o lat. blastemare ou blastimare é uma forma dissimilada de blasphemare (Ernout-Meillet). Será isto suficiente? E' provável que houvesse ai uma intenção.

Ao cap. 12 - Tabus em nomes de espíritos malignos:

São Jerônimo chamou ao demônio Ninguém - "Nomine persequente, id est daemone" (Pe. M. Bernardes, "Nova Floresta". II, 1949, p. 291).

No latim eclesiástico, era o demônio também chamado antiquus hostis, antiquus serpens; ao lado de diabolus empregou-se zabulus (Aqui houve deformação? $\mathrm{O} z$ era pronunciado $\mathbf{d z}$ ).

Má-geira (feminino) é um provincianismo beirão, e quer dizer "diabo" (Figueiredo). Será o mesmo que megera ? Outro provincianismo beirão, com o mesmo sentido, é provinco (Figueiredo). E provincianismo sem outra determinação - zarapelho (Figueiredo). também aplicado ao demo. 